\title{
Friendliness to Animals and Verbal Aggressiveness to People: Using Prison Inmates Education Networks as an Illustration
}

\author{
Nikolaos Hasanagas, Alexandra Bekiari, Periklis Vasilos \\ Faculty of Physical Education and Sports Science, University of Thessaly, Thessaly, Greece \\ Email: sandrab@pe.uth.gr
}

How to cite this paper: Hasanagas, N., Bekiari, A. and Vasilos, P. (2017) Friendliness to Animals and Verbal Aggressiveness to People: Using Prison Inmates Education Networks as an Illustration. Social Networking, 6, 224-238.

https://doi.org/10.4236/sn.2017.63015

Received: June 23, 2017

Accepted: July 14, 2017

Published: July 17, 2017

Copyright $\odot 2017$ by authors and Scientific Research Publishing Inc. This work is licensed under the Creative Commons Attribution International License (CC BY 4.0).

http://creativecommons.org/licenses/by/4.0/

\begin{abstract}
Goal of this research is to detect possible relations between animal-related attitudes and verbal aggressiveness as well as types combining such parameters. The sample collected in 2015 contains two adult education classes equivalent to secondary school level (class $\mathrm{A}=23$ inmates and $\mathrm{B}=12$ inmates, all male) at a correctional facility. Questionnaires were used. Network analysis software (Visone) and conventional statistics (SPSS) are used for calculating network variables (indegree, outdegree, katz, pageranketc) and implementing Spearman test and Principal Component Analysis. Inmates who have adopted an animal-friendly value system and are too coward to react against torture of animals, maintain a repressed emotion. If they do not intervene and provoke, then they are also not targeted by others. No reaction against torture is also connected with a deep-rooted aggressiveness. Concerning superficial aggressiveness, a profile, whose characterize is multiple verbal aggressiveness, can be attributed to repressed emotions. A type is torturing and indifferently restricts his aggressiveness, as he can satisfy his need of dominance by being aggressive towards animals. A type of inmate who loves animals and reacts against their torture, presents the most restricted and relatively smooth aggressiveness, as he discharges his repressed emotions to this reaction. Under condition of indifference, keeping pets is not evidence of loving but of a need of companionship. As for the deep-rooted aggressiveness (over-extroversion), it does not seem to be triggered by any repression.
\end{abstract}

\section{Keywords}

Animal Friendliness And Cruelty, Verbal Aggressiveness,

Inmates Classes, Social Network Analysis

\section{Introduction}

The expected academic significance of this research lies in the innovative setting 
of the network samples consisting of inmates of correction facilities (particularly in education units) and in connecting attitudes toward animals with verbal aggressiveness as a structural phenomenon. The practical significance is supposed to consist in the detection of types of behaviors and attitudes and in understanding of aggressiveness and animal friendliness or cruelty phenomenon.

Verbal aggressiveness has extensively been investigated in multifarious environments (family, business, education system etc.) [1]-[8]. Impacts of verbal aggressiveness in the education system have also been discussed regarding motivation [9]-[18], attraction [19] [20], affective learning [21] [22], discipline [23], satisfaction and learning [24] [25] [26] [27], fair play behaviours [28], Machiavellianism [29] [30], even in correctional facilities [31] [32]. However, it has not been explored in relation to animal friendliness. Is the animal abuse or hatred an extension of overflowing aggressiveness which cannot be discharged on people?

It has already been supported that there is a positive relation between animal cruelty and violence (from homicide to family violence) [33] [34] [35] [36] [37]. Dominant hypotheses on this issue are that overflowing aggressiveness or hatred against human beings is supposed to occur on animals or that the same violence which is directed against human beings of society in general, is also directed against animals. However, these studies focus only on physical aggression (violence). There is no study on the possible relation between animal cruelty and verbal aggressiveness, or inversely, between animal friendliness and non-aggressiveness.

As verbal aggressiveness is a main variable in this research, social network analysis is an appropriate method (considering inmates classes as networks) [38]-[48].

\section{Aim and Innovation}

Aim of this research is to explore the relation between animal friendliness and verbal aggressiveness (or non-aggressiveness) in adult education classes (secondary school) in correctional facility.

The expected academic innovation consists in:

-An education unit within a correctional facility is expected to be an ideal setting for exploring this issue, as classes of inmates are closed societies supposed to enclose affluent verbal aggressiveness. In this way, the occurrence of verbal aggressiveness is expected to be more intensive and discernible. Thus, more clear quantitative results are supposed to be revealed and correlated with the degree of animal friendliness (or cruelty) of each inmate.

-understanding the relation between aggressiveness structures and attitudes toward animals considering the parameters as determinants and effects.

-pointing out typologies (profile settings) combining animal-related attitudes and relation with aggressiveness.

The expected practical innovation consists in enabling:

- the recognition of afore-mentioned types of behaviors and attitudes.

- the detection and exploration of behavioral phenomena. 


\section{Method}

\subsection{Sampling}

Two network samples of correctional facility inmates were collected in 2015. The sample contains two adult education classes equivalent to secondary school level (class $\mathrm{A}=23$ inmates and $\mathrm{B}=12$ inmates, all male) at the correctional facility. The class A was composed of inmates 22 - 64 years old (average 36) and the class B of inmates 25 - 43 years old (average 33). In these samples of inmates a great variety of professions were to be found (i.e. technician, farmer, carpenter, builder, driver, electrician, blacksmith etc). In total, 13 inmates had finished the primary school, 18 the secondary school, 2 the high school and 1 inmate the higher education. The facility was not randomly selected but just because it was the only opportunity. The researchers are ethically committed to keep secret not only the names of the inmates but even the facility and the country where it was located. This commitment was a prerequisite for the participation of the inmates in the research. This non randomness and full secrecy can reasonably not supposed to weaken any reliability or cognitive substance of this research, as its goal is to produce results about correlations and not to produce generalizable descriptive statistics for any particular country or social settings.

\subsection{Questionnaire}

The network-related part of questionnaire was based on previous research [49]. Moreover, this part was completed with approaches of [50] and [31] [38] concerning the concept of social power. The questionnaires were enriched with more questions about verbal aggressiveness (threat, harming etc.). The non-network part of the questionnaire contained animal-related questions. Focusing on dimensioning the whole possible behavioral patterns and attitudes toward animals was the basic principle of the non-network part of the questionnaire. Expert interview was also conducted with correctional and education staff. This interview was important for the final formulation of the questionnaire.

\subsection{Process}

Basic network variables (indegree, outdegree, Katz status, pagerank, authority) were calculated by Visone 1.1. This software is advantageous enough, as it not only calculates, but also visualizes and layers the network analysis results. The secondary network variables, namely over-extroversion (differential and ratio), as defined in [31], were calculated with SPSS. In this study, the variable "strongly established" has been calculated as the ratio of katz to in degree. The correlation (Spearman test) was conducted between network and non-network variables in order to detect effects or determinants. Principal Component Analysis between network variables for formulating typology has also been conducted with SPSS 16.

Spearman test provides a good overview on all possible relations making the effects comparable. Therefore, it is preferred to multivariate analysis. Spearman 
test and the Principal Component Analysis were implemented for similar analysis in previous research [51] [52] [53].

\section{Results and Discussion}

In Figure 1, selected network examples are presented. The selected relations are companion in class and making someone ridiculous. The networks of class B

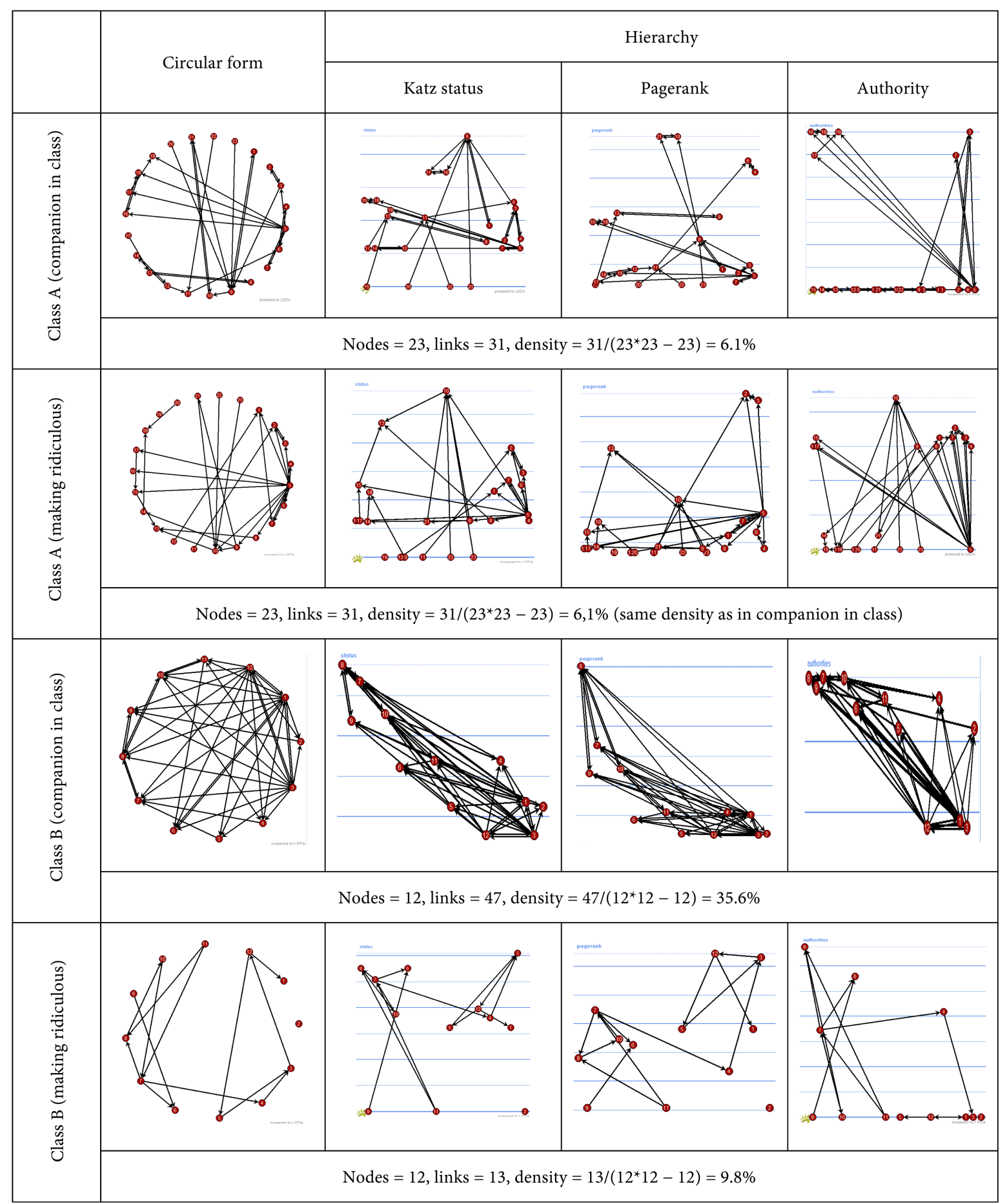

Figure 1. Selected network examples from secondary adult education in correctional facility. 
present remarkably higher density than these of class A respectively. This can be attributed both to the fact that on this occasion the nodes (inmates) in class $B$ are fewer than in class $\mathrm{A}$, but also to the fact that the inmates who are now in class B had already spent more time together in class A and thus, became familiarized.

It is also noticeable that companionship and aggressiveness are equally dense in class A (6.1\%) while in class B the aggressiveness is much thinner (9.8\%) than the companionship (35.6\%). Thus, in the course of time, the companionship looks to dominate and the aggressiveness to decline, in the particular examples.

In the Table 1, being worried but no reacting against torture of animal characterizes a multi-criticizer (regarding abilities, character, milieu, appearance). Obviously, a person who has adopted an animal-friendly value system but he is too coward to react against torture of animals he maintains a repressed emotion which finds an aggressive outlet toward other inmates.

On the other hand, inmates who become targets of criticism tend to be those who keep a quite friendly attitude toward animals. This could be attributed to a

Table 1. Animal friendliness and criticism.

\begin{tabular}{|c|c|c|c|c|c|c|}
\hline & & $\begin{array}{l}\text { like to } \\
\text { keep dog }\end{array}$ & $\begin{array}{l}\text { like to } \\
\text { keep fish }\end{array}$ & $\begin{array}{l}\text { loving } \\
\text { animals }\end{array}$ & $\begin{array}{c}\text { no reacting } \\
\text { if someone } \\
\text { tortures } \\
\text { animal }\end{array}$ & $\begin{array}{c}\text { indifferent } \\
\text { if someone } \\
\text { tortures } \\
\text { animal }\end{array}$ \\
\hline \multirow{8}{*}{$\begin{array}{c}\text { Verbal } \\
\text { aggressor }\end{array}$} & out degree of & 0.140 & -0.158 & 0.074 & $0.387\left(^{*}\right)$ & 0.088 \\
\hline & criticizing abilities & 0.423 & 0.365 & 0.673 & 0.021 & 0.617 \\
\hline & out degree of & 0.119 & -0.010 & 0.036 & $0.434\left(^{* *}\right)$ & -0.072 \\
\hline & criticizing character & 0.495 & 0.954 & 0.836 & 0.009 & 0.682 \\
\hline & out degree of & 0.006 & -0.123 & 0.180 & $0.441(* *)$ & -0.142 \\
\hline & criticizing milieu & 0.972 & 0.480 & 0.301 & 0.008 & 0.415 \\
\hline & out degree of & 0.072 & 0.109 & 0.174 & $0.370(*)$ & -0.216 \\
\hline & criticizing appearance & 0.681 & 0.533 & 0.317 & 0.029 & 0.213 \\
\hline \multirow{12}{*}{$\begin{array}{l}\text { Verbally } \\
\text { aggressed }\end{array}$} & page rank of & $0.338(*)$ & -0.039 & $0.392\left(^{*}\right)$ & 0.196 & -0.182 \\
\hline & criticizing abilities & 0.047 & 0.826 & 0.020 & 0.260 & 0.295 \\
\hline & page rank of & 0.329 & -0.039 & $0.466\left({ }^{* *}\right)$ & $0.486(* *)$ & $-0.420\left(^{*}\right)$ \\
\hline & criticizing character & 0.053 & 0.826 & 0.005 & 0.003 & 0.012 \\
\hline & $\begin{array}{l}\text { page rank of } \\
\text { criticizing }\end{array}$ & 0.026 & 0.253 & $0.523\left(^{* *}\right)$ & 0.221 & -0.054 \\
\hline & & 0.883 & 0.143 & 0.001 & 0.201 & 0.759 \\
\hline & in degree of criticizing & 0.092 & 0.194 & $0.386(*)$ & 0.052 & -0.271 \\
\hline & appearance & 0.598 & 0.264 & 0.022 & 0.767 & 0.116 \\
\hline & authority of criticizing & -0.035 & $0.410(*)$ & 0.206 & -0.065 & -0.163 \\
\hline & appearance & 0.844 & 0.014 & 0.235 & 0.712 & 0.351 \\
\hline & page rank of & 0.075 & 0.038 & $0.403(*)$ & 0.235 & -0.213 \\
\hline & criticizing appearance & 0.667 & 0.827 & 0.016 & 0.175 & 0.218 \\
\hline
\end{tabular}


sentimental weakness which makes these persons emotionally vulnerable or repressed and, thereby, easily targeted by other inmates. Those who have been worried about tortured animals but they would have been too coward to react against it, are characterized by obvious fear which also constitutes them easily targeted by other inmates. The indifference to possible torture of animal apparently reveals a generalized indifference to any violent incident or unfairness. Thereby, indifference makes an inmate not provocative to others and increases his invulnerability.

Just as in Table 1 non reaction against torture of animal leads to emotional repression, which results in multi-level criticism as outbursts, so in Table 2, no reaction leads similarly to curse. Simultaneously, the tendency to react against violence exerted on animals reduces the tendency to curse. In other words, curse seems to be a clear outlet for repressed emotions. Furthermore, the indifference appears once again to be a safe way of life which reduces the targeting, just as in Table 1.

In Table 3, once again verbal aggressiveness (in form of mockery) appears as an outburst of emotions repressed by a generalized attitude of non reaction. Loving animals also indicates a sentimental weakness which becomes obvious

Table 2. Animal friendliness and curse.

\begin{tabular}{|c|c|c|c|c|c|}
\hline & & $\begin{array}{l}\text { indifferent to } \\
\text { torture }\end{array}$ & $\begin{array}{c}\text { no reacting } \\
\text { if someone } \\
\text { tortures } \\
\text { animal }\end{array}$ & $\begin{array}{l}\text { reacting if } \\
\text { someone } \\
\text { tortures animal }\end{array}$ & $\begin{array}{l}\text { indifferent if } \\
\text { someone } \\
\text { tortures animal }\end{array}$ \\
\hline \multirow{4}{*}{$\begin{array}{c}\text { Verbal } \\
\text { aggressor }\end{array}$} & out degree of curse & -0.033 & $0.440(* *)$ & $-0.371\left(^{*}\right)$ & 0.095 \\
\hline & & 0.850 & 0.008 & 0.028 & 0.589 \\
\hline & in degree of curse & $-0.344\left(^{*}\right)$ & 0.103 & 0.141 & $-0.344\left(^{*}\right)$ \\
\hline & & 0.043 & 0.558 & 0.419 & 0.043 \\
\hline \multirow{4}{*}{$\begin{array}{l}\text { Verbally } \\
\text { aggressed }\end{array}$} & katz of curse & $-0.341\left(^{*}\right)$ & 0.166 & 0.104 & $-0.341\left(^{*}\right)$ \\
\hline & & 0.045 & 0.341 & 0.554 & 0.045 \\
\hline & Page rank of curse & $-0.342\left(^{*}\right)$ & $0.355\left(^{*}\right)$ & -0.009 & $-0.419\left(^{*}\right)$ \\
\hline & & 0.045 & 0.036 & 0.960 & 0.012 \\
\hline
\end{tabular}

Table 3. Animal friendliness and mockery.

\begin{tabular}{cccccc}
\hline & & $\begin{array}{c}\text { loving } \\
\text { animals }\end{array}$ & $\begin{array}{c}\text { in different } \\
\text { to animals }\end{array}$ & $\begin{array}{c}\text { tortured } \\
\text { animals }\end{array}$ & $\begin{array}{c}\text { no reacting if } \\
\text { someone } \\
\text { tortures animal }\end{array}$ \\
\hline $\begin{array}{c}\text { Verbal } \\
\text { aggressor }\end{array}$ & out degree of mockery & 0.112 & 0.000 & -0.108 & $\mathbf{0 . 4 1 7}\left(^{*}\right)$ \\
& authority of mockery & -0.012 & $\mathbf{0 . 3 7 7}\left(^{*}\right)$ & $\mathbf{0 . 3 4 3}\left(^{*}\right)$ & -0.203 \\
Verbally & & 0.523 & 1.000 & 0.538 & 0.241 \\
aggressed & page rank of mockery & $\mathbf{0 . 5 2 2 ( * * )}$ & -0.111 & -0.036 & 0.054 \\
& & 0.001 & 0.524 & 0.838 & 0.760 \\
\hline
\end{tabular}


in everyday life in prison. As a result of this, inmates who love animals tend to be targeted for mockery. However, paradoxically, the opposite case, namely the experience of having tortured animal also constitutes an inmate target of mockery. This could be attributed to the fact that inmates characterized by repressed tendencies cannot keep in their outbursts. Thus, they become an easy target of mockery by others.

Finally, it is also noticeable that the indifference to violence exerted against animals does not assure any neutrality and invulnerability like in the case of curse (Table 2) and in the case of criticism (Table 1). Specifically in the case of mockery, the indifferent inmates tend to be targeted, as they seem to abandon not only any action toward thirds but also defense for themselves.

In Table 4, inmates who would like to keep pet and consider themselves to love animals or they would react against animal torture tend to be ridiculous among the other inmates. On the other hand, no reaction and indifference to animal torture tend to characterize inmates who are not susceptible to become ridiculous. This can be attributed to the fact that inmates with such distinct feelings and awareness are negatively distinguished. However, if they do not intervene and provoke, then they also are not targeted by others. The results of Table 5 and Table 6 can be similarly interpreted.

In Table 7, the desire to keep a pet as well as reaction against torturing animal

Table 4. Animal friendliness and ridicule.

\begin{tabular}{|c|c|c|c|c|c|c|}
\hline & & $\begin{array}{c}\text { like to } \\
\text { keep dog }\end{array}$ & $\begin{array}{l}\text { Loving } \\
\text { animals }\end{array}$ & $\begin{array}{c}\text { reacting if } \\
\text { someone } \\
\text { tortures } \\
\text { animal }\end{array}$ & $\begin{array}{c}\text { no reacting } \\
\text { if someone } \\
\text { tortures } \\
\text { animal }\end{array}$ & $\begin{array}{c}\text { indifferent } \\
\text { if someone } \\
\text { tortures } \\
\text { animal }\end{array}$ \\
\hline \multirow{8}{*}{$\begin{array}{c}\text { Verbally } \\
\text { aggressed }\end{array}$} & \multirow{2}{*}{$\begin{array}{l}\text { in degree of } \\
\text { rediculous }\end{array}$} & 0.232 & 0.283 & 0.300 & -0.094 & $-0.394\left(^{*}\right)$ \\
\hline & & 0.181 & 0.099 & 0.080 & 0.592 & 0.019 \\
\hline & \multirow{2}{*}{$\begin{array}{l}\text { status of } \\
\text { rediculous }\end{array}$} & 0.275 & 0.315 & 0.295 & -0.061 & $-0.418\left(^{*}\right)$ \\
\hline & & 0.109 & 0.066 & 0.086 & 0.729 & 0.013 \\
\hline & \multirow{2}{*}{$\begin{array}{c}\text { authority of } \\
\text { rediculous }\end{array}$} & 0.051 & 0.148 & $0.454\left(^{* *}\right)$ & $-0.377\left(^{*}\right)$ & -0.251 \\
\hline & & 0.769 & 0.396 & 0.006 & 0.026 & 0.146 \\
\hline & \multirow{2}{*}{$\begin{array}{l}\text { page rank of } \\
\text { rediculous }\end{array}$} & $0.371\left(^{*}\right)$ & $\left.0.381{ }^{*}\right)$ & 0.187 & 0.153 & $-0.438\left(^{* *}\right)$ \\
\hline & & 0.028 & 0.024 & 0.283 & 0.381 & 0.009 \\
\hline
\end{tabular}

Table 5. Animal friendliness and threat.

\begin{tabular}{|c|c|c|c|c|c|}
\hline & & $\begin{array}{c}\text { like to } \\
\text { keep dog }\end{array}$ & $\begin{array}{l}\text { like to } \\
\text { keep cat }\end{array}$ & $\begin{array}{c}\text { loving } \\
\text { animals }\end{array}$ & $\begin{array}{c}\text { indifferent if } \\
\text { someone } \\
\text { tortures anima }\end{array}$ \\
\hline \multirow{4}{*}{$\begin{array}{c}\text { Verbally } \\
\text { aggressed }\end{array}$} & authority & 0.037 & $\left.0.395{ }^{*}\right)$ & 0.185 & -0.146 \\
\hline & of threat & 0.831 & 0.019 & 0.287 & 0.402 \\
\hline & page rank & $0.394\left(^{*}\right)$ & 0.294 & $0.348\left(^{*}\right)$ & $-0.341\left(^{*}\right)$ \\
\hline & of threat & 0.019 & 0.086 & 0.040 & 0.045 \\
\hline
\end{tabular}


Table 6. Animal friendliness and harassment.

\begin{tabular}{cccccc}
\hline & & $\begin{array}{c}\text { like to } \\
\text { keep fish }\end{array}$ & $\begin{array}{c}\text { like to } \\
\text { keep other pet }\end{array}$ & $\begin{array}{c}\text { loving } \\
\text { animals }\end{array}$ & $\begin{array}{c}\text { no reacting if } \\
\text { someone } \\
\text { tortures animal }\end{array}$ \\
\hline \multirow{2}{*}{$\begin{array}{c}\text { Verbally } \\
\text { aggressed }\end{array}$} & harassment & $\mathbf{0 . 0 1 7}$ & $\mathbf{0 . 0 1 6}$ & 0.294 & $\mathbf{0 . 0 0 1}$ \\
& $\begin{array}{c}\text { page rank of } \\
\text { harassment }\end{array}$ & 0.067 & 0.018 & $\mathbf{0 . 3 4 9}\left({ }^{*}\right)$ & 0.217 \\
& & 0.701 & 0.917 & $\mathbf{0 . 0 4 0}$ & 0.211 \\
\hline
\end{tabular}

Table 7. Animal friendliness and deep-rooted aggressiveness.

\begin{tabular}{|c|c|c|c|c|c|}
\hline & & $\begin{array}{l}\text { like to } \\
\text { keep dog }\end{array}$ & $\begin{array}{l}\text { like to } \\
\text { keep fish }\end{array}$ & $\begin{array}{c}\text { reacting if } \\
\text { someone } \\
\text { tortures animal }\end{array}$ & $\begin{array}{l}\text { no reacting } \\
\text { if someone } \\
\text { tortures animal }\end{array}$ \\
\hline \multirow{10}{*}{$\begin{array}{c}\text { Verbal } \\
\text { aggressor }\end{array}$} & \multirow{2}{*}{$\begin{array}{l}\text { strong established of } \\
\text { criticize (ratio) }\end{array}$} & 0.148 & -0.260 & $-0.415\left(^{*}\right)$ & 0.120 \\
\hline & & 0.397 & 0.131 & 0.013 & 0.491 \\
\hline & \multirow{2}{*}{$\begin{array}{c}\text { overextrovert } \\
\text { of threat (difference) }\end{array}$} & $-0.347\left(^{*}\right)$ & -0.013 & -0.047 & -0.022 \\
\hline & & 0.041 & 0.941 & 0.789 & 0.901 \\
\hline & \multirow{2}{*}{$\begin{array}{l}\text { overextrovert } \\
\text { of threat (ratio) }\end{array}$} & $-0.394\left(^{*}\right)$ & 0.039 & 0.000 & -0.007 \\
\hline & & 0.019 & 0.826 & 1.000 & 0.967 \\
\hline & \multirow{2}{*}{$\begin{array}{c}\text { overextrovert of } \\
\text { harassment (ratio) }\end{array}$} & 0.091 & $-0.336\left(^{*}\right)$ & $-0.370\left(^{*}\right)$ & $0.380\left(^{*}\right)$ \\
\hline & & 0.602 & 0.048 & 0.029 & 0.024 \\
\hline & \multirow{2}{*}{$\begin{array}{c}\text { overextrovert of } \\
\text { harassment (difference) }\end{array}$} & 0.165 & $-0.399\left(^{*}\right)$ & $-0.439(* *)$ & $0.415\left(^{*}\right)$ \\
\hline & & 0.342 & 0.017 & 0.008 & 0.013 \\
\hline
\end{tabular}

show a non aggressive personality. No reaction against torture is connected with a deep-rooted aggressiveness.

In the Table 8, five types of inmates are pointed out, which combine attitudes towards animals and superficial aggressive behavior in prison. The first type is the "loving but not reacting" inmate. This is an inmate who loves animals, but he would not react to any animal torture made by third persons. This profile is characterized by multiple verbal aggressiveness. This can be attributed to repressed outbursts.

The second type is the "torturing and indifferent". This an inmate who is susceptible to torture animals or remain indifferent to this, but he is going to be aggressive in terms of verbal harassment and insulting. The restriction of his aggressiveness on these two forms of aggression can be attributed that he satisfies his need of dominance by being aggressive towards animals.

The third type, "loving and reacting", seems to contain much less aggressiveness. An inmate who tend to both love animals and react against animal torture, presents the most restricted and relatively smooth aggressiveness (only making others ridiculous). This can be understood, as a result of discharging his repressed emotions to this reaction. Thus, he does not need to externalize outbursts to his inmates. Simultaneously, loving animals shows a smooth idiosyncrasy which tends to retain outbursts. 
Table 8. Attitude towards animals and superficial aggressiveness.

\begin{tabular}{|c|c|c|c|c|c|c|}
\hline & & $\begin{array}{l}\text { loving but } \\
\text { not reacting }\end{array}$ & $\begin{array}{c}\text { torturing and } \\
\text { indifferent }\end{array}$ & $\begin{array}{l}\text { loving and } \\
\text { reacting }\end{array}$ & reacting & torturing \\
\hline \multirow{10}{*}{ 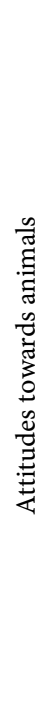 } & like to keep dog & 0.397 & 0.065 & 0.633 & -0.396 & -0.055 \\
\hline & like to keep cat & 0.242 & -0.311 & 0.227 & 0.467 & -0.100 \\
\hline & like to keep no pet & -0.034 & 0.283 & -0.545 & 0.107 & 0.438 \\
\hline & loving animals & 0.331 & -0.130 & 0.564 & -0.443 & -0.134 \\
\hline & in different to animals & -0.203 & -0.083 & -0.108 & 0.378 & 0.176 \\
\hline & tortured animals & 0.009 & 0.535 & 0.130 & 0.298 & 0.352 \\
\hline & $\begin{array}{l}\text { indifferent to } \\
\text { animal torture }\end{array}$ & 0.036 & 0.763 & 0.012 & 0.020 & -0.107 \\
\hline & $\begin{array}{c}\text { no reacting if } \\
\text { someone tortures animal }\end{array}$ & 0.670 & -0.216 & -0.274 & -0.385 & 0.193 \\
\hline & $\begin{array}{l}\text { reacting if someone } \\
\text { tortures animal }\end{array}$ & -0.469 & -0.378 & 0.468 & 0.381 & 0.148 \\
\hline & $\begin{array}{c}\text { indifferent if } \\
\text { someone tortures animal }\end{array}$ & 0.143 & 0.691 & -0.163 & 0.083 & -0.365 \\
\hline \multirow{8}{*}{ 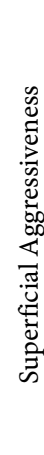 } & out degree of total critisize & 0.662 & -0.351 & -0.300 & -0.085 & -0.097 \\
\hline & out degree of curse & 0.652 & -0.070 & -0.027 & 0.372 & -0.075 \\
\hline & out degree of mockery & 0.567 & -0.341 & -0.103 & -0.156 & 0.468 \\
\hline & out degree of rediculous & 0.459 & -0.171 & 0.348 & 0.133 & 0.316 \\
\hline & out degree of threat & 0.536 & -0.279 & -0.235 & 0.453 & -0.105 \\
\hline & out degree of harassment & 0.619 & 0.534 & 0.259 & 0.162 & 0.184 \\
\hline & out degree of insult & 0.513 & 0.589 & 0.254 & 0.169 & 0.000 \\
\hline & out degree of harm & 0.483 & -0.278 & -0.285 & 0.257 & -0.457 \\
\hline
\end{tabular}

Extraction Method: Principal Component Analysis, 7 components extracted.

The "reacting" type is clearly connected with indifference to animals. However, it contains a desire to keep a pet. Under the condition of indifference, this is not so clearly an evidence of loving but rather a need of personal companion. At the same time, this type tends to be reactive against any animal torture committed by third persons. Thus, this type seems to be rather stimulated by ecumenical values of ethics and integrity like the respect to any living entity or the defense against any torturing.

The "torturing" type is an inmate who desire no pet at home and have tortured animal. Thus, it is a quite clear type. As he has already discharged outbursts on animals, he needs to be aggressive to his inmates in just a few and relatively smooth ways (mockery and making others ridiculous).

In the Table 9, three types of inmates are presented, which combine attitudes towards animals and deep-rooted aggressiveness. The first type is an inmate who is "indifferent and not reacting" to any torture of animals. Although this type does not seem to have any repressed emotions regarding animals, he presents a multiple aggressiveness towards other inmates. In contrast to the Table 8, where 
Table 9. Attitudes towards animals and deep-rooted aggressiveness.

\begin{tabular}{|c|c|c|c|c|}
\hline & & $\begin{array}{l}\text { indifferent and } \\
\text { not reacting }\end{array}$ & loving & $\begin{array}{c}\text { torturing and } \\
\text { indifferent }\end{array}$ \\
\hline \multirow{8}{*}{$\begin{array}{l}\text { Attitudes } \\
\text { towards } \\
\text { animals }\end{array}$} & like to keep dog & 0.199 & 0.571 & -0.483 \\
\hline & like to keep cat & 0.019 & 0.407 & -0.229 \\
\hline & like to keep no pet & 0.124 & -0.430 & 0.365 \\
\hline & loving animals & 0.001 & 0.535 & -0.417 \\
\hline & tortured animals & 0.211 & 0.226 & 0.568 \\
\hline & indifferent to animal torture & 0.466 & 0.093 & 0.460 \\
\hline & $\begin{array}{l}\text { no reacting if someone } \\
\text { tortures animal }\end{array}$ & 0.391 & -0.159 & -0.674 \\
\hline & $\begin{array}{l}\text { indifferent if someone } \\
\text { tortures animal }\end{array}$ & 0.533 & -0.038 & 0.448 \\
\hline \multirow{8}{*}{$\begin{array}{c}\text { Deep-rooted } \\
\text { Aggressiveness }\end{array}$} & $\begin{array}{l}\text { overextroversion of } \\
\text { total criticizing (differential) }\end{array}$ & 0.563 & -0.347 & -0.385 \\
\hline & overextrovert critisize (ratio) & 0.559 & -0.368 & -0.212 \\
\hline & overextrovert threat difference & 0.444 & -0.430 & 0.119 \\
\hline & overextrovert threat ratio & 0.444 & -0.497 & 0.177 \\
\hline & overextrovert verb harass ratio & 0.770 & 0.157 & -0.114 \\
\hline & overextrovert verb harass difference & 0.799 & 0.274 & 0.036 \\
\hline & overextrovert insult hand difference & 0.562 & 0.629 & 0.366 \\
\hline & overextrovert insult hand ratio & 0.470 & 0.648 & 0.171 \\
\hline
\end{tabular}

Extraction Method: Principal Component Analysis, 7 components extracted.

superficial aggressiveness seems to be related with repressed emotions, in Table 9, the deep-rooted aggressiveness (over-extroversion), as expected, does not seem to be triggered by any repression. Inversely, a person with deep-rooted aggressiveness discharges it at any rate to other inmates, even without having experienced any repression in his life.

The second type is "loving" animals and could also be a pet keeper. This type is connected with a restricted but rough aggressiveness (insulting with hand). This is an evidence of replacing the value and the belief in human being with the value and belief in animals. He tends to search for an emotional refuge at the animals companion while simultaneously he is hostile to other inmates.

Finally, the "torturing and indifferent" type shows a quite clear tendency to abuse animals. When someone maintains so clear intention to abuse animals, then he discharges most aggressiveness in this way, and thereby, his aggressiveness to other inmates is quite restricted on insulting with hand. Similar typologies have already been suggested [54] [55] [56] [57].

\section{Conclusions}

Inmates, who have adopted an animal-friendly value system and are too coward to react against torture of animals, maintain a repressed emotion. Animal-re- 
lated sentiments make persons easily targeted by other inmates. Those who are coward to react against animal abuse are characterized by fear which also makes them easily targeted by others. In difference, it makes a not provocative inmate and increases his invulnerability. The indifference to violence exerted against animals does not assure any neutrality and invulnerability specifically in the case of mockery. No reaction and indifference to animal torture tend to characterize inmates who are not susceptible to become ridiculous. If they do not intervene and provoke, then they are also not targeted by others. No reaction against torture is also connected with a deep-rooted aggressiveness. Several types have been suggested which connect attitudes towards animals and aggressiveness. Concerning superficial aggressiveness, a profile, whose characterize is multiple verbal aggressiveness, can be attributed to repressed emotions. A type is torturing and indifferently restricts his aggressiveness, as he can satisfy his need of dominance by being aggressive towards animals. A type of inmate who loves animals and reacts against their torture, presents the most restricted and relatively smooth aggressiveness, as he discharges his repressed emotions to this reaction. Under condition of indifference, keeping pets is not evidence of loving but of a need of companionship. Reacting against animal torture may be stimulated by ecumenical values of integrity like the respect to any living entity. There is also clear type of "torturing" type, who has already discharged outbursts on animals and he is aggressive to his inmates in just a few and smooth ways. As for the deep-rooted aggressiveness (over-extroversion), it does not seem to be triggered by any repression. A tendency of searching for an emotional refuge at the animals' companionship and hostility to other inmates has also been detected. There is such a clear tendency to abuse animals, discharging most aggressiveness in this way, and thereby, restricting aggressiveness to other inmates.

The restriction of the sampling only on one prison is a limitation of this research. A future challenge is to extend the sample to other prisons of various countries. In this way, not only a larger but also a multi-cultural inmate sample can be collected. More parameters and relations can also be examined and further in-depth interviews can be conducted in future research.

\section{References}

[1] Anderson, C.M. and Martin, M.M. (1995) Why Employees Speak to Coworkers and Bosses: Motives, Gender, and Organizational Satisfaction. The Journal of Business Communication, 32, 249-265. https://doi.org/10.1177/002194369503200303

[2] Bekiari, A. and Sakellariou, K. (2003) Perceived Instructor Verbal Aggressiveness and Student State Learning in Physical Education. Italian Journal of Sport Sciences, 1, 251-256.

[3] Bekiari, A. and Manoli, P. (2016) EFL Teacher Verbal Aggressiveness and Argumentativeness and Student Socio-Affective Strategy Use and Affective Learning: Exploring Possible Associations. Journal of Teacher Education and Educators, 5, 154-171.

[4] Infante, D.A., Myers, S.A., and Buerkel, R.A. (1994) Argument and Verbal Aggression in Constructive and Destructive Family and Organizational Disagreements. 
Western Journal of Communication (Includes Communication Reports), 58, 73-84. https://doi.org/10.1080/10570319409374488

[5] Infante, D.A. and Rancer, A.S. (1996) Argumentativeness and Verbal Aggressiveness: A Review of Recent Theory and Research. Annals of the International Communication Association, 19, 319-352. https://doi.org/10.1080/23808985.1996.11678934

[6] Infante, D.A. and Wigley III, C.J. (1986) Verbal Aggressiveness: An Interpersonal Model and Measure. Communications Monographs, 53, 61-69. https://doi.org/10.1080/03637758609376126

[7] Manoli, P. and Bekiari, A. (2015) EFL Teachers' Verbal Aggressiveness and Students' Intrinsic Motivation and Social-Affective Strategy Use: Investigating Possible Relations. Advances in Research, 5, 1-13. https://doi.org/10.9734/AIR/2015/19692

[8] Rancer, A.S. and Avtgis, T.A. (2014) Argumentative and Aggressive Communication: Theory, Research, and Application. 2nd Edition, Peter Lang, New York.

[9] Bekiari, A. (2014) Verbal Aggressiveness and Leadership Style of Sports Instructors and their Relationship with Athletes' Intrisic Motivation. Creative Education, 5, 114-121. https://doi.org/10.4236/ce.2014.52018

[10] Bekiari, A., Kokaridas, D. and Sakellariou, K. (2005) Verbal Aggressiveness of Physical Education Teachers and Students' Self-Reports of Behaviour. Psychological Reports, 96, 493-498. https://doi.org/10.2466/pr0.96.2.493-498

[11] Bekiari, A., Kokaridas, D. and Sakellariou, K. (2006) Associations of Students' SelfReports of Their Teacher's Verbal Aggression, Intrinsic Motivation, and Perceptions of Reasons for Discipline in Greek Physical Education Classes. Psychological Reports, 98, 451-461. https://doi.org/10.2466/pr0.98.2.451-461

[12] Bekiari, A. and Tsiana, I. (2016) Exploring Instructors' Verbal Aggressiveness and Students' Personal Orientations and Reasons of Discipline in Physical Education Class. Advances in Physical Education, 6, 158-168.

https://doi.org/10.4236/ape.2016.63018

[13] Bekiari, A. and Syrmpas, I. (2015) Coaches' Verbal Aggressiveness and Motivational Climate as Predictors of Athletes' Satisfaction. British Journal of Education, Society \& Behavioural Science, 9, 318-329. https://doi.org/10.9734/BJESBS/2015/17757

[14] Claus, C.J., Chory, R.M. and Malachowski, C.C. (2011) The Relationship between Instructor Aggressive Communication Traits and Student Antisocial Behavioural Alteration Techniques. Annual Meeting of the Eastern Communication Association, Alexandria.

[15] Schrodt, P. (2003) Students' Appraisals of Instructors as a Function of Students' Perceptions of Instructors' Aggressive Communication. Communication Education, 52, 106-121. https://doi.org/10.1080/03634520302468

[16] Myers, S.A., Edwards, C., Wahl, S.T. and Martin, M.M. (2007) The Relationship between Perceived Instructor Aggressive Communication and College Student Involvement. Communication Education, 56, 495-508. https://doi.org/10.1080/03634520701466398

[17] Myers, S.A. and Knox, R.L. (1999) Verbal Aggression in the College Classroom: Perceived Instructor Use and Student Affective Learning. Communication Quarterly, 47, 33-45. https://doi.org/10.1080/01463379909370122

[18] Myers, S.A. and Rocca, K.A. (2001) Perceived Instructor Argumentativeness and Verbal Aggressiveness in the College Classroom: Effects on Student Perceptions of Climate, Apprehension, and State Motivation. Western Journal of Communication (Includes Communication Reports), 65, 113-137. 
https://doi.org/10.1080/10570310109374696

[19] Bekiari, A. and Petanidis, D. (2016) Exploring Teachers' Verbal Aggressiveness through Interpersonal Attraction and Students' Intrinsic Motivation. Open Journal of Social Sciences, 4, 72-85. https://doi.org/10.4236/jss.2016.412007

[20] Syrmpas, I. and Bekiari, A. (2015) The Relationship between Perceived Physical Education Teacher's Verbal Aggressiveness and Argumentativeness with Students' Interpersonal Attraction. Inquiries in Sport \& Physical Education, 13, 21-32.

[21] Bekiari, A. (2012) Perceptions of Instructors' Verbal Aggressiveness and Physical Education Students' Affective Learning. Perceptual and Motor Skills, 115, 325-335. https://doi.org/10.2466/06.11.16.PMS.115.4.325-335

[22] Bekiari, A. and Tsaggopoulou, Th. (2016) Verbal Aggressiveness and Affective Learning in Physical Education. Advances in Physical Education, 6, 406-418. https://doi.org/10.4236/ape.2016.64041

[23] Bekiari, A. and Pylarinou, M. (2017) Instructor Argumentativeness and Socio-Communicative Style and Student Discipline: Using Physical Education Students' Class as an Illustration. Open Journal of Social Sciences, 5, 122-136. https://doi.org/10.4236/jss.2017.53011

[24] Bekiari, A., Digelidis, N. and Sakellariou, K. (2006) Perceived Verbal Aggressiveness of Coaches in Volleyball and Basketball: A Preliminary Study. Psychological Reports, 103, 526-530.

[25] Bekiari, A., Koustelios, A. and Sakellariou, K. (2000) Instructors' Verbal Aggressiveness from Universities in Greece. Studie Ricerche, 5, 225-232.

[26] Bekiari, A., Patsiaouras, A., Kokaridas, D. and Sakellariou, K. (2006) Verbal Aggressiveness and State Anxiety of Volleyball Players and Coaches. Psychological Reports, 99, 630-634. https://doi.org/10.2466/pr0.99.2.630-634

[27] Bekiari, A., Perkos, S. and Gerodimos, V. (2015) Verbal Aggression in Basketball: Perceived Coach Use and Athlete Intrinsic and Extrinsic Motivation. Journal of Physical Education and Sport, 15, 96-102.

[28] Hassandra, M., Bekiari, A. and Sakellariou, K. (2007) Physical Education Teacher's Verbal Aggression and Student's Fair Play Behaviors. The Physical Educator, 64, 94-101.

[29] Bekiari, A. (2016) Insights into Instructors' Verbal Aggressiveness and Students' Machiavellianism through Leadership Style and Motivational Climate. European Scientific Journal, 12, 90-110. https://doi.org/10.19044/esj.2016.v12n25p90

[30] Bekiari, A. (2017) Exploring Relations between Instructors' Verbal Aggressiveness and Argumentativeness and Students' Fair Play Behaviours and Machiavellianism. International Journal of Physical Education, 54.

[31] Bekiari, A. andHasanagas, N. (2016c) Suggesting Indicators of Superficiality and Purity in Verbal Aggressiveness. An Application in Adult Education Class Networks of Prisoners. Open Journal of Social Sciences, 4, 279-292. https://doi.org/10.4236/jss.2016.43035

[32] Hasanagas, N. and Bekiari, A. (2017) An Exploration of the Relation between Hunting and Aggressiveness: Using Inmates Networks at Prison Secondary School as an Illustration. Social Networking, 6, 19-37. https://doi.org/10.4236/sn.2017.61002

[33] Arluke, A. and Madfis, E. (2014) Animal Abuse as a Warning Sign of School Massacres: A Critique and Refinement. Homicide Studies, 18, 7-22. https://doi.org/10.1177/1088767913511459

[34] DeGue, S. and DiLillo, D. (2009) Is Animal Cruelty a "Red Flag" for Family Vi- 
olence? Investigating Co-Occurring Violence toward Children, Partners, and Pets. Journal of Interpersonal Violence, 24, 1036-1056. https://doi.org/10.1177/0886260508319362

[35] Flynn, C.P. (2011) Examining the Links between Animal Abuse and Human Violence. Crime, Law and Social Change, 55, 453-468.

https://doi.org/10.1007/s10611-011-9297-2

[36] McPhedran, S. (2009) A Review of the Evidence for Associations between Empathy, Violence, and Animal Cruelty. Aggression and Violent Behavior, 14, 1-4.

[37] Volant, A.M., Johnson, J.A., Gullone, E. and Coleman, G.J. (2008) The Relationship between Domestic Violence and Animal Abuse an Australian Study. Journal of Interpersonal Violence, 23, 1277-1295. https://doi.org/10.1177/0886260508314309

[38] Bekiari, A. and Hasanagas, N. (2015) Verbal Aggressiveness Exploration through Complete Social Network Analysis: Using Physical Education Students' Class as an Illustration. International Journal of Social Science Studies, 3, 30-49. https://doi.org/10.11114/ijsss.v3i3.729

[39] Bekiari, A. and Hasanagas, N. (2016a) Sociological Insights in the Education System: "Unlocking" the Power Relations (orig. in Greek). AfoiKyriakidi Editions S.A., Thessaloniki.

[40] Bekiari, A. andHasanagas, N. (2016b) "Educating” in Physical Education. Theoretical Approaches and Practical Inquiries (orig. in Greek). AfoiKyriakidi Editions S.A., Thessaloniki.

[41] Bekiari, A., Hasanagas, N., Theoharis, D., Kefalas, I. and Vasilou, A. (2015) The Role of Mathematical Object and the Educational Environment to Students' Interpersonal Relationships: An Application of Full Social Network Analysis. Proceedings of the 32 nd Congress Greek Mathematical Society (with International Participation), Kastoria, 799-812.

[42] Bekiari, A. and Pachi, V. (2017) Insights into Bullying and Verbal Aggressiveness through Social Network Analysis. Journal of Computer and Communications, 5, 79-101. https://doi.org/10.4236/jcc.2017.59006

[43] Bekiari, A. and Spyropoulou, S. (2016) Exploration of Verbal Aggressiveness and Interpersonal Attraction through Social Network Analysis: Using University Physical Education Class as an Illustration. Open Journal of Social Sciences, 4, 145-155. https://doi.org/10.4236/jss.2016.46016

[44] Hasanagas, N. and Bekiari, A. (2015) Depicting Determinants and Effects of Intimacy and Verbal Aggressiveness Target through Social Network Analysis. Sociology Mind, 5, 162-175. https://doi.org/10.4236/sm.2015.53015

[45] Theoharis, D. and Bekiari, A. (2016a) The Influence of Mathematics and Learning Environment in Verbal Aggressiveness and Interpersonal Relations: A Dynamic Analysis of Social Networks. Proceedings of the 8 th International Congress Mathematical Society, Thessaloniki, 30 March-3 April 2016, 415-428.

[46] Theoharis, D. and Bekiari, A. (2016) Social Networks Analysis of Centrality: Case Study in Leadership Networks. Proceedings of the 33rd Congress Greek Mathematical Society (with International Participation), Chania, 4-6 November 2016, 250 260.

[47] Theoharis, D. and Bekiari, A. (2017) Applying Social Network Indicators in the Analysis of Verbal Aggressiveness at the School. Journal of Computer and Communications, 5, 169-181.

[48] Theoharis, D. and Bekiari, A. (2017b) Cumulative Hierarchy Analysis (Katz Centrality) on Leadership Networks of Learning Communities. Proceedings of the 9 th 
International Congress Mathematical Society, Thessaloniki, 17-19 March 2017, 285297.

[49] Bekiari, A. and Digelidis, N. (2015) Measuring Verbal Aggressiveness in Sport and Education. International Journal of Physical Education, 52, 12-21.

[50] Popitz, H. (1992) Phänomene der macht. Mohr Siebeck.

[51] Bekiari, A., Deliligka, S. and Hasanagas, N. (2017) Analysing Networks of Verbal Aggressiveness and Motivation. Psychology, 8, 495-515. https://doi.org/10.4236/psych.2017.83031

[52] Bekiari, A., Nikolaidou, Z. and Hasanagas, N. (2017) Typology of Motivation and Aggression on the Basis of Social Network Variables: Examples of Complementary and Nested Behavioral Types through Conventional Statistics. Social Networking, 6, 135-147. https://doi.org/10.4236/sn.2017.62008

[53] Theoharis, D., Bekiari, A. and Koustelios, A. (2017) Exploration of Determinants of Verbal Aggressiveness and Leadership through Network Analysis and Conventional Statistics. Using School Class as an Illustration. Sociology Mind, 7, 27-43. https://doi.org/10.4236/sm.2017.72003

[54] Bekiari, A. (2017) Verbally Aggressive Instructors and Machiavellian Students: Is the Socio-Communicative Style an Over-Bridging? Journal of Computer and Communications.

[55] Bekiari, A. and Balla, K. (2017) Instructors and Students Relations: Argumentativeness, Leadership and Goal Orientations. Open Journal of Social Sciences.

[56] Bekiari, A., Deliligka, S. and Koustelios, A. (2016) Examining Relations of Aggressive Communication in Social Networks. Social Networking, 6, 38-52. https://doi.org/10.4236/sn.2017.61003

[57] Bekiari, A., Pachi, V. and Hasanagas, N. (2017) Investigating Bullying Determinants and Typologies with Social Network Analysis. Journal of Computer and Communications, 5, 11-27. https://doi.org/10.4236/jcc.2017.57002

Submit or recommend next manuscript to SCIRP and we will provide best service for you:

Accepting pre-submission inquiries through Email, Facebook, LinkedIn, Twitter, etc. A wide selection of journals (inclusive of 9 subjects, more than 200 journals) Providing 24-hour high-quality service

User-friendly online submission system

Fair and swift peer-review system

Efficient typesetting and proofreading procedure

Display of the result of downloads and visits, as well as the number of cited articles

Maximum dissemination of your research work

Submit your manuscript at: http://papersubmission.scirp.org/

Or contact sn@scirp.org 